\title{
CAMELLIA QUYNHII (THEACEAE, SECT. STEREOCARPUS), A NEW YELLOW SPECIES FROM THE CENTRAL HIGHLANDS, VIETNAM
}

\author{
Quach Van Hoi ${ }^{a, b^{*}}$, Luong Van Dung ${ }^{c}$, Hoang Thanh Truong ${ }^{d}$, Nong Van Duy ${ }^{b}$, \\ Bui Danh Chung, , Roman V. Doudkin ${ }^{\mathrm{a}, \mathrm{g}}$ \\ ${ }^{a}$ School of Natural Sciences, Far Eastern Federal University, Vladivostok, Russia \\ ${ }^{b}$ Tay Nguyen Institute for Scientific Research, Vietnam Academy of Science and Technology, Lam Dong, \\ Vietnam \\ ${ }^{c}$ Biology Department, Dalat University, Lam Dong, Vietnam \\ ${ }^{d}$ Forest Science Institute of Central Highlands and South of Central Viet Nam, Vietnamese Academy of \\ Forest Science, Lam Dong, Vietnam \\ ${ }^{e}$ School of Biomedicine, Far Eastern Federal University, Vladivostok, Russia \\ ${ }^{f}$ North East College of Agriculture and Forestry, Quang Ninh, Vietnam \\ ${ }^{g}$ Botanical Garden-Institute FEB RAS, Vladivostok, Russia \\ *Corresponding author: Email: quachvanhoi@gmail.com
}

\section{Article history}

Received: February $1^{\text {st }}, 2021$

Received in revised form: May $19^{\text {th }}, 2021 \mid$ Accepted: May $28^{\text {th }}, 2021$

Available online: November $8^{\text {th }}, 2021$

\begin{abstract}
Camellia quynhii is described and illustrated as a new species of section Stereocarpus (Pierre) Sealy from $12^{\text {th }}$ village, Vu Bon Commune, Krong Pak District, Dak Lak Province. C. quynhii resembles $C$. dormoyana (Pierre) Sealy but differs in several morphological characteristics: sepals 6-7; petals about 12-15; filaments tomentose at the base; style 3(4), basally united; capsule 3(-4) locular, 2-6 seeds in each locule. Information on its phenology, distribution, ecology, and conservation status is also provided.
\end{abstract}

Keywords: Camellia quynhii; Central Highlands; Dak Lak; Theaceae; Vietnam.

DOI: http://dx.doi.org/10.37569/DalatUniversity.12.3.848(2022)

Article type: (peer-reviewed) Full-length research article

Copyright () 2021 The author(s).

Licensing: This article is licensed under a CC BY-NC 4.0 


\section{INTRODUCTION}

Camellia L. is the largest genus of the Theaceae family, which comprises 120 to 280 species extending from Bhutan, Northeast India, China and Japan to Indonesia and the Philippines (Chang \& Bartholomew, 1984; Ming \& Bartholomew, 2007; Nguyễn, 2017; Sealy, 1958). The genus is characterized by having seeds without wings and capsules dehiscing from the apex (Sealy, 1958). Vietnam is considered a major center of diversity of Camellia with about 95 species (Nguyễn, 2017; Lê et al., 2020; PhạmHoàng, 1999; Trần, 2002). Recently, many additional new species of Camellia have been discovered and described from southern Vietnam (Lương, Hoàng et al., 2016a; Lương, Lê et al., 2016b; Lưu et al., 2018; Quach et al., 2021). This area has great potential for many undiscovered Camellia species.

In November 2020, two field surveys were carried out in Krong Pak District, Dak Lak Province. We successfully collected the flowers and fruit of an unnamed Camellia species. The morphological features of the samples were compared with specimens stored in herbaria (HN), (VNM), and (DLU), as well as online digital images from the Muséum National d'Histoire Naturelle (https://science.mnhn.fr/), the Chinese Virtual Herbarium (http://www.cvh.ac.cn/) and JSTOR Global Plants (https://plants.jstor.org/). After analyzing and comparing the morphological features with close species, we assert that this is a new species, which we name Camellia quynhii. In this paper, this new species from Vietnam is described and its taxonomic position assessed in the system of Ming and Bartholomew (2007). It is placed in Camellia sect. Stereocarpus (Pierre) Sealy, 1958 (Ming \& Bartholomew, 2007).

\section{TAXONOMIC TREATMENT}

- Camellia quynhii Luong, Quach \& Hoang, sp. nov. (Figures 1, 2)

- Vernacular name: Vietnamese: Trà hoa quỳnh

\subsection{Type}

Vietnam, Dak Lak Province, Krong Pak District, Vu Bon Commune, $12^{\text {th }}$ village, around point $12^{\circ} 35^{\prime} 48.9^{\prime \prime} \mathrm{N}, 108^{\circ} 27^{\prime} 01.0^{\prime \prime} \mathrm{E}$, evergreen broadleaf forest on mountain slopes with basaltic red soil, elevation 550-600 m, 01 Jan. 2020, Quach Van Hoi, Hoang Thanh Truong, Luong Van Dung, DL 201101 (holotype, isotype DLU).

\subsection{Description}

Shrub or small evergreen tree, 2-4 m high; young branches brownish, sparsely pubescent and becoming glabrous. Leaves stalked; blades elliptic or broad elliptic, 14$20(-22.5) \mathrm{cm}$ long, 9-12 cm wide, blades thick and coriaceous, glabrous, apex obtuse or shortly acute, margins serrate, base rounded or cordate, shining and deep green above, light green below; lateral veins 7-10 pairs, sunken above and protruding below; petioles stout, curved, 0.8-1.0 cm long, glabrous. Flowers light yellow, almost sessile, solitary (rarely two), terminal, upward, $6.0-7.5 \mathrm{~cm}$ in diameter. Bracteoles 2-4, opposite, 
triangular, 3.0-11 mm long, 3.0-4.0 $\mathrm{mm}$ wide, pubescent on both surfaces, persistent. Sepals 6-7, scale or nearly rounded, $0.5-1.2 \mathrm{~cm}$ long, $0.5-1.5 \mathrm{~cm}$ wide, pubescent on both surfaces, persistent. Petals 12-15, suborbicular to broad elliptic, in three whorls, first whorl 5-6, suborbicular to broad elliptic, $1.0-3.7 \mathrm{~cm}$ long, $1.7-2.7 \mathrm{~cm}$ wide, pubescent on both surfaces; second whorl 5-6, broad elliptic, 4.0-4.4 cm long, 2.3$2.7 \mathrm{~cm}$ wide, pubescent on both surfaces; third whorl 2-3, broad elliptic, $4.5-4.1 \mathrm{~cm}$ long, 1.7-2.0 cm wide. Androecium 2.5-3.2 cm long, stamens numerous, in 5-6 whorls, outer filaments united $0.9-1.2 \mathrm{~cm}$, tomentose at the base. Gynoecium 3(-4) locular, ovary ovate, ribbed, 4-5 mm long, 4-4.5 mm wide, glabrous; style 3(-4), 2.7-3.1 cm long, united $1 / 5$ or $1 / 6$ of length from the base, glabrous. Capsule ovoid, $5-5.6 \mathrm{~cm}$ high, $4.0-4.5 \mathrm{~cm}$ diameter, 3(-4) locular, 2-6 seeds in each loculus, furfuraceous, pericarp 4$5 \mathrm{~mm}$ thick, columella $2-2.3 \mathrm{~cm}$ high. Seeds rounded on the back and wedge-shaped on the face, 1.4-1.6 cm long, 0.9-1.2 cm wide, dark brown, pubescent.

\subsection{Phenology}

Camellia quynhii flowers from November to January of the following year and fruits from June to September.

\subsection{Distribution and ecology}

The distribution of this species is known only from one mountain in $12^{\text {th }}$ village, $\mathrm{Vu}$ Bon Commune, Krong Pak District, Dak Lak Province. It is located on mountain slopes in evergreen broadleaf forests along the boundaries between plantations and forest.

\subsection{Conservation status}

It is estimated that fewer than 200 individuals of $C$. quynhii are known from only one population that occupies an area of less than 1 hectare. The location is currently threatened by deforestation and agricultural expansion. Therefore, C. quynhii can be assessed as critically endangered (CR) according to IUCN categories and criteria (IUCN, 2019).

\subsection{Etymology}

The specific epithet of this species honors Mr. Nguyen Ngoc Quynh, a local person who discovered this species.

\subsection{Taxonomic remarks}

Prior to this paper, Camellia sect. Stereocarpus included a total of four species: C. dormoyana (Sealy, 1958), C. pubipetala, C. luteoflora (Ming \& Bartholomew, 2007), and C. maiana (Orel \& Wilson, 2010). Two of the species, C. dormoyana and C. maiana, are present in Vietnam (Orel \& Wilson, 2010; Sealy, 1958). Morphological features that allow us to place the $C$. quynhii species in sect. Stereocarpus include the following: flowers light yellow, almost sessile, solitary (rarely two), terminal; bracteoles and sepals persistent; petals yellow, basally connate; outer filaments united $0.9-1.2 \mathrm{~cm}$; 
style 3(-4), connate (Ming \& Bartholomew, 2007). C. quynhii is most morphologically similar to $C$. dormoyana in having young branches pubescent, flowers yellowish, solitary, terminal, almost sessile; bracteoles 2-4, opposite, inserted close to and much smaller than the sepals, persistent; stamens united with outer petals; gynoecium glabrous. However, it is different in having outer whorl tomentose at the base, ovary 3(4) locular, style united $1 / 5$ or $1 / 6$ of length from the base, larger capsule (5-5.6 x 4.0$4.5 \mathrm{~cm}$ ), 2-6 seeds in each locule, light furfuraceous (Pierre, 1887; Sealy, 1958). It is also easily distinguishable from other species of sect. Stereocarpus by young branches pubescent, flower yellowish, style glabrous (C. maiana) (Orel \& Wilson, 2010), by ovary glabrous, petals $12-15$, capsule ovoid, 3(-4) locular (C. pubipetala), and by ovary glabrous, bigger flower and capsule, 2-6 seeds in each locule (C. luteoflora) (Ming \& Bartholomew, 2007).

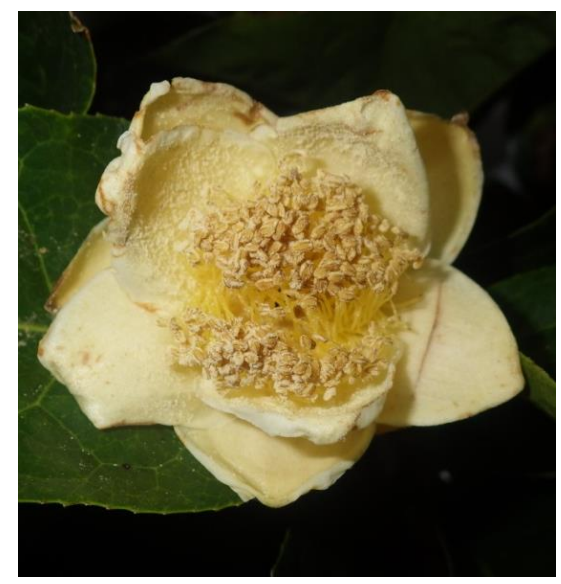

(a)

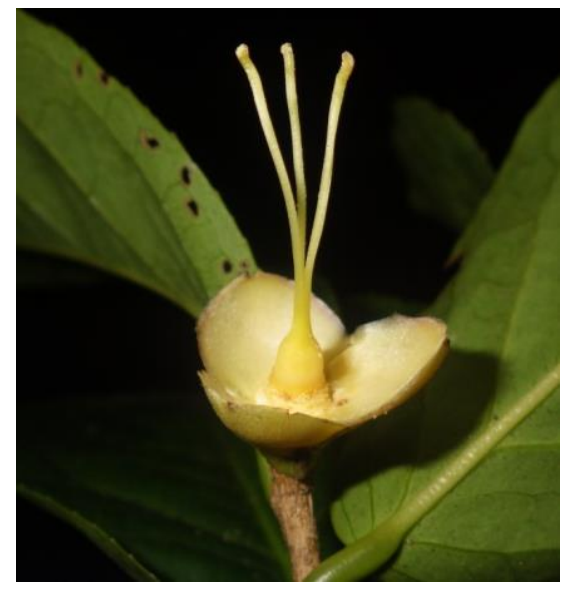

(c)

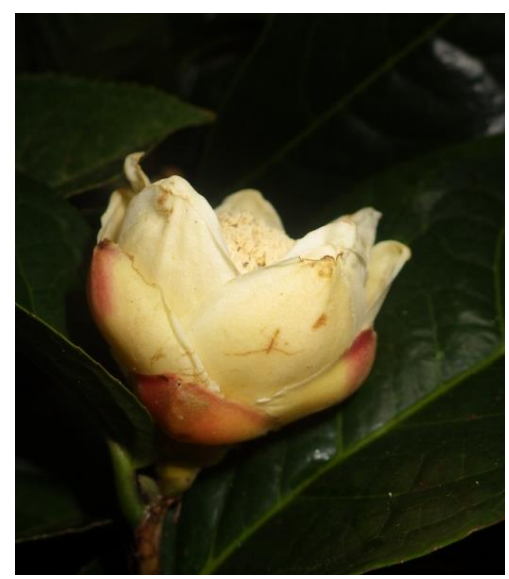

(b)

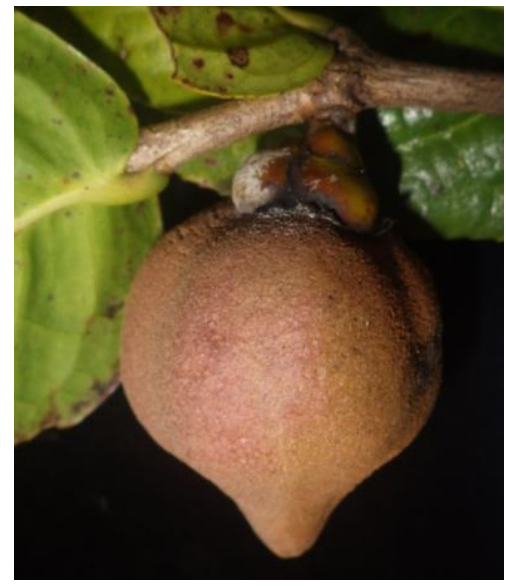

(d)

Figure 1. Camellia quynhii

Note: (a), (b) Flower; (c) Sepals and gynoecium; (d) Fruit.

Source: Photographs by Luong Van Dung. 

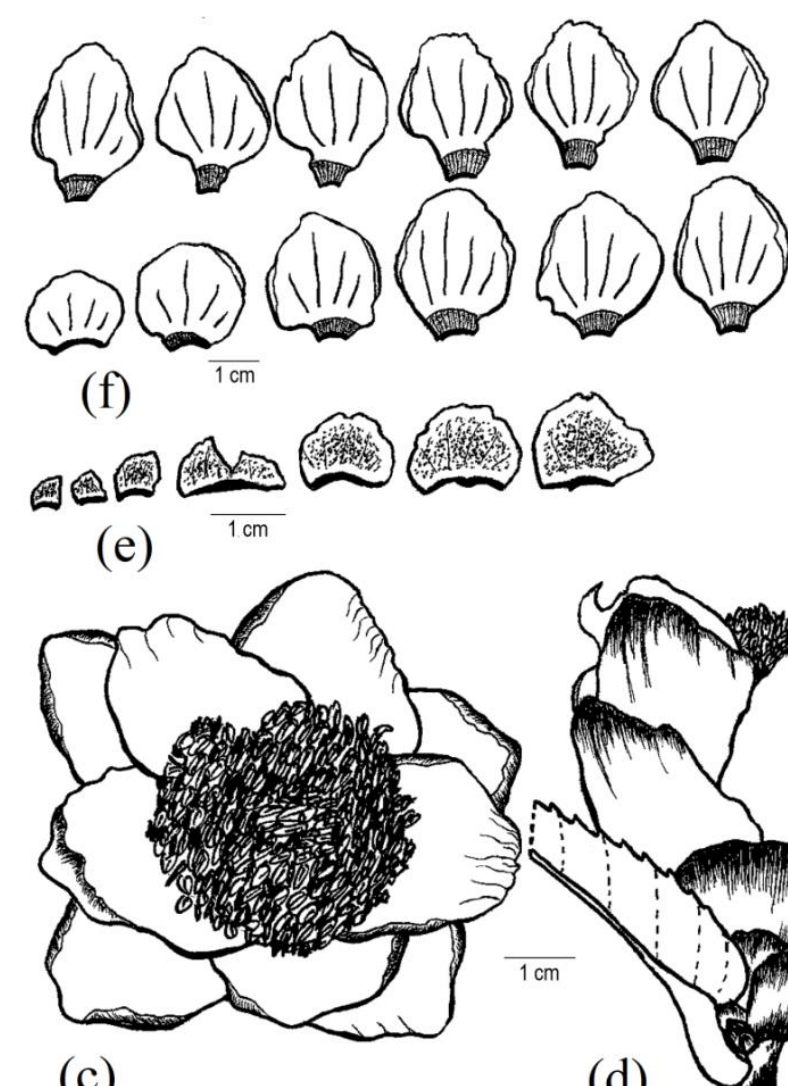

(c)

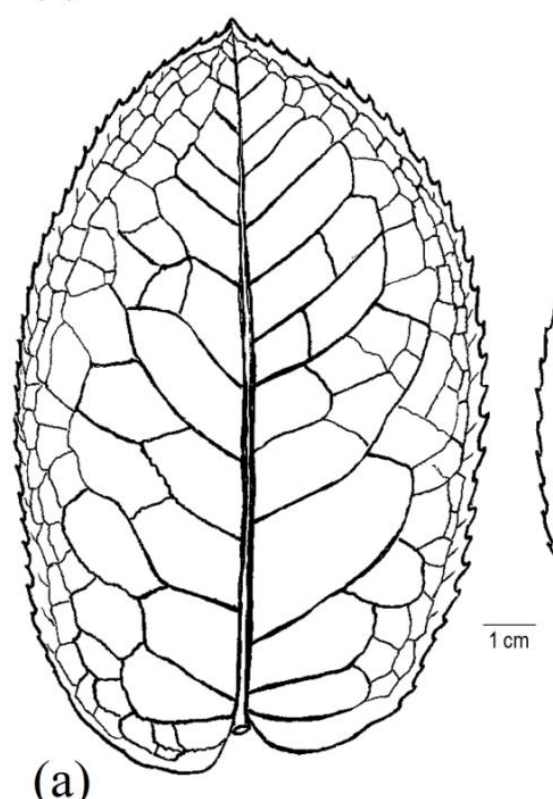

(d)
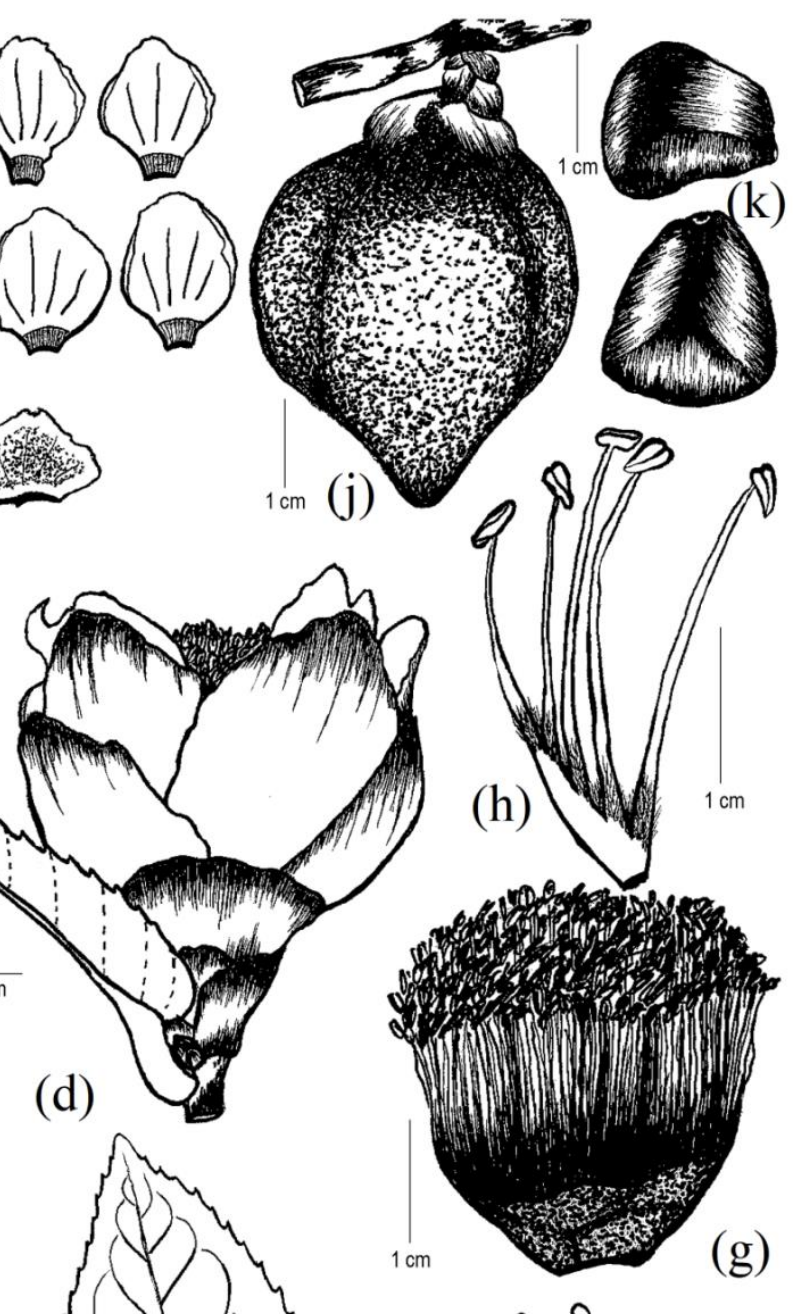
Table 1. Morphological comparison between $C$. quynhii and $C$. dormoyana

\begin{tabular}{lll}
\hline Characters & C. quynhii (This study) & C. dormoyana (Sealy, 1958) \\
\hline Tree & $2-4$ m high & $6-10 \mathrm{~m}$ high \\
Young branches & sparsely pubescent & glabrous \\
Leaves & & oval, oblong, ovate \\
Shape & elliptic or broad elliptic & $11-18 \times 5.5-8 \mathrm{~cm}$ \\
Size & $14-20(-22.5) \times 9-12 \mathrm{~cm}$ & shortly acute \\
Apex & obtuse or shortly acute & rounded \\
Base & rounded, cordate & \\
Flower & & about $5.5 \mathrm{~cm}$ in diameter \\
Size & $6.0-7.5 \mathrm{~cm}$ in diameter & $5-6$ \\
Sepal & $6-7$ & about 12 \\
Petal & $12-15$ & glabrous \\
Filament & tomentose at the base & $5(-6)$, united completely \\
Style & $3(-4)$, united $1 / 5$ or $1 / 6$ of length from the base & $5(-6)$ locular \\
Ovary & $3(-4)$ locular & \\
Fruit & & depressed globose, 5 locular \\
Shape & ovoid, $3(-4)$ locular & about $2.5 \times 3.5 \mathrm{~cm}$ \\
Size & $5-5.6 \times 4.0-4.5 \mathrm{~cm}$ & $(2)-3$ seeds in each loculus, $1.0 \times 0.7-0.8 \mathrm{~cm}$ \\
Seed & $2-6$ seeds in each loculus, 1.4-1.6 x 0.9-1.2 cm & \\
\hline
\end{tabular}

\section{KEY TO THE SPECIES OF CAMELLIA SECT. STEREOCARPUS}

1a. Flower white, in a group of 2-4(5) C. maiana

1b. Flower yellow, solitary (rarely 2) 2

2a. Ovary $5(-6)$ locular C. dormoyana

2b. Ovary 3(-4) locular 3

3a. Ovary glabrous C. quynhii

3b. Ovary tomentose 4

4a. Flowers $5-6 \mathrm{~cm}$ in diam.; filaments pilose C. pubipetala

4b. Flowers $1-1.8 \mathrm{~cm}$ in diam.; filaments glabrous C. luteoflora 


\section{ACKNOWLEDGMENTS}

This study was partially supported by the Department of International Cooperation, Vietnamese Ministry of Education and Training.

\section{REFERENCES}

Chang, H. T., \& Bartholomew, B. (1984). Camellias. B. T. Batsford Ltd.

IUCN. (2019). Guidelines for using the IUCN red list categories and criteria, version 14. https://cmsdocs.s3.amazonaws.com/RedListGuidelines.pdf

Lê, N. H. N., Lương, V. D., Nguyễn, V. C., Phạm, T. T. D., Lưu, T. T., \& Phạm, V. T. (2020). An updated checklist of Theaceae and a new species of Polyspora from Vietnam. Taiwania, 65(2), 216-227. https://taiwania.ntu.edu.tw/pdf/tai.2020.65.216.pdf

Lương, V. D., Hoàng, T. S., Trần, N., \& Phạm, H. N. (2016a). Camellia quangcuongii (Theaceae), a new species from Vietnam. Journal of Japanese Botany, 91(4), 226-230.

Lương, V. D., Lê, A., Nguyễn, T. H., \& Nguyễn, T. L. (2016b). Camellia thuongiana A new yellow Camellia species from Vietnam. Dalat University Journal of Science, 6(3), 338-344. https://doi.org/10.37569/DalatUniversity.6.3.78(2016)

Lưu, H. T., Trần, G., Nguyễn, Q. D., \& Nguyễn, H. C. (2018). A new species of the family Theaceae from central Vietnam. Academia Journal of Biology, 40(4), 2328. https://doi.org/10.15625/2615-9023/v40n4.12919

Ming, T. L., \& Bartholomew, B. (2007). Theaceae. In Z.-Y. Wu, P. H. Raven, \& D. Y. Hong (Eds.), Flora of China Vol. 12. Hippocastanaceae through Theaceae (pp. 366-478). Science Press; Missouri Botanical Garden Press.

Nguyễn, H. H. (2017). Thục vật chí Việt Nam [Flora of Vietnam]. Họ Chè - Theaceae D. Don, Vol. 19. (pp. 128-147). NXB. Khoa học Tự nhiên và Công nghệ.

Orel, G., \& Wilson P. G. (2010). A new species of Camellia sect. Stereocarpus (Theaceae) from Vietnam. Novon, 20(2), 198-202. https://doi.org/10.3417/2008096

Phạm-Hoàng, H. (1999). Theaceae. In H. Phạm-Hoàng (Ed.), Cây cỏ Việt Nam [An illustrated flora of Vietnam] Vol. 1. (pp. 424-432). NXB. Tré.

Pierre, L. (1887). Flore Forestière de Cochinchine, Vol. 2. Octave Doin.

Quach, V. H., Luong, V. D., Doudkin, R. V., Averyanov, L. V., Bui, B. T., Nguyen, T. L., \& Luu, H. T. (2021). Camellia proensis (Theaceae, sect. Piquetia), a new species from Southern Vietnam. Phytotaxa, 479(1), 137-141. https://doi.org/10. 11646/phytotaxa.479.1.12

Sealy, J. R. (1958). A revision of the genus Camellia. Royal Horticultural Society.

Trần, N. (2002). Biodiversity of the genus Camellia of Vietnam. International Camellia Journal, 34, 80-85. 